\title{
Finnur Dellsén
}

\section{Að treysta sérfræơingum}

\section{Hvar, hvenær og hvers vegna?}

\section{Inngangur}

Á Borgarafundi um loftslagsmál í Ríkisútvarpinu pann 19. nóvember 2019 var eitt umræðuefnið hvers vegna við ættum að trúa peim sérfræðingum sem segja loftslagsbreytingar vera af mannavöldum. Guðni Elísson sem er prófessor í bókmenntafræði við Háskóla Íslands ${ }^{1}$ benti á að „okkar samfélag ... gengur út á pað að við berum traust til sérfræðinga.“2 Við treystum til dæmis læknum til að segja til um pað hvernig eigi að lækna kvilla pegar börnin okkar verða veik og verkfræðingum til að segja til um hvernig eigi að tryggja að brýr og vegir hafi nægilegt burðarbol. Rök Guðna voru sumsé pau að við ættum pví einnig að treysta loftslagsvísindafólki, sem segir okkur nánast einróma að loftslagsbreytingar séu raunverulegar og að miklu leyti af mannavöldum. ${ }^{3}$

1 Guðni hefur barist ötullega fyrir pví að horfast í augu við loftslagsvandann, meðal annars með pví að stofna loftslagsvefinn Earth101 og með pví að skrifa fjölda fræðilegra greina um loftslagsmál og umræðuna um hana, bæði hérlendis og erlendis. Sjá meðal annars Guðni Elísson, „Nú er úti veður vont. Gróðurhúsaáhrif og íslensk umræðuhefð“, Ritið 1/2007, bls. 5-44; „Efahyggja og afneitun. Ábyrg loftslagsumræða í fjölmiðlafári samtímans“, Ritið 2/2008, bls. 77-114; „Dómsdagsklukkan tifar. Upplýsing og afneitun í umræðu um loftslagsbreytingar“, Ritið 1/2011, bls. 91-136.

2 Borgarafundur um loftslagsmál, Ríkisútvarpið, 19. nóvember 2019.

3 John Cook, Naomi Oreskes, Peter T. Doran, William R. L. Anderegg, Bart Verheggen, Ed W. Maibach, J. Stuart Carlton, Stephan Lewandowsky, Andrew G. Skuce, Sarah A. Green, Dana Nuccitelli, Peter Jacobs, Mark Richardson, Bärbel Winkler, Rob Painting og Ken Rice, „Consensus on Consensus. A Synthesis of Consensus Estimates on Human-Caused Global Warming“, Environmental Research Letters 2016/11, nr. 048002.

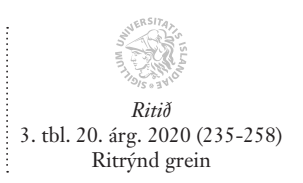

(C) 2020 Ritið, tímarit Hugvísindastofnunar og höfundur greinarinnar

Útgefandi:

Hugvísindastofnun Háskóla Íslands, Sæmundargötu 2, 102 Reykjavík
Birtist á vefnum http://www.ritid.hi.is. Tengiliður: ritið@hi.is

DOI: $10.33112 /$ ritid.20.3.10

Birt samkvæmt skilmálum Creative Commons BY (4.0). 
Óhætt er að taka undir með Guðna að samfélag okkar byggist á trausti til ýmissa sérfræðinga, par á meðal til lækna og loftslagsvísindafólks. Hins vegar vekur petta strax upp erfiða spurningu, bví ekki eru allir sem segjast eða virðast hafa sérfræðipekkingu raunverulega traustsins verðir. Hvernig vitum við hvort tiltekinn „sérfræðingur“ sé pað í raun og veru? Á pessum sama Borgarafundi um loftslagsmál voru til dæmis tvær manneskjur sem stóðu hlið við hlið og sögðu mjög ólíka sögu um hvort loftslagsbreytingar væru af mannavöldum, veðurfræðingurinn Elín Björk Jónasdóttir og blaðakonan Erna Ýr Öldudóttir. Sú fyrrnefnda hefur stundað rannsóknir á sviði loftslagsmála og hefur menntun í samræmi við bað, ${ }^{4}$ en sú síðarnefnda var boðin í páttinn vegna pess að hún hafði tjáð sig um efnið á samfélagsmiðlum. Mörgum lesendum pessarar greinar pykir eflaust augljóst hvor peirra Ernu og Elínar er raunverulegur sérfræðingur á sviði loftslagsmála. Vandinn er sá að pað er ekki víst að öllum pyki pað jafn augljóst, auk pess sem til eru ótal mörg önnur svið par sem skilin milli sérfræðinga og annarra eru mun óljósari en í pessu tiltekna dæmi.

Sú hugmynd að almenningur eigi að treysta sérfræðingum virðist líka að sumu leyti stangast á við pá áherslu á sjálfstæða skoðanamyndun sem meðal annars hefur gætt í íslenskri umræðu og menntastefnu. Margir íslenskir heimspekingar hafa lagt áherslu á mikilvægi gagnrýninnar hugsunar, sem Páll Skúlason skilgreindi með eftirminnilegum hætti sem „sú hugsun sem fellst ekki á neina skoðun eða fullyrðingu nema hún hafi fyrst rannsakað hvað í henni felst og fundið fullnægjandi rök fyrir henni. “5 Hugsunin

4 Sjá til dæmis meistararitgerð hennar: Elín Björn Jónasdóttir, „Enhancement of the albedo of low stratus marine clouds. Simulations in a global climate model“, Háskólinn í Osló, 2012.

5 Páll Skúlason, „Er hægt að kenna gagnrýna hugsun?“, Pelingar, Reykjavík: Ergo, 1987, bls. 67-92, hér bls. 70. Svipaða skilgreiningu á gagnrýninni hugsun er einnig að finna í nýlegri grein Páls, „Kreppa háskóla og kjarni háskólastarfs“, Skírnir 1/2007, bls. 381-405, hér bls. 403. Í síðarnefndu greininni tekur Páll fram að gagnrýnin hugsun sé fyrst og fremst megindygð freðilegrar starfsemi á borð við rannsóknir í háskólum; venjuleg eða hversdagsleg skoðanamyndun eigi hins vegar að einkennast af ýmsum öðrum pekkingardyggðum á borð við óhlutdrægni, hugrekki og dómgreind (sama rit, bls. 398-399).

Af öðrum ritum íslenskra heimspekinga um gagnrýna hugsun má nefna Róbert H. Haraldsson, „Gagnrýnin hugsun og veruleiki. Um sjálfsögð sannindi og vísindalega aðferð“, Tveggja manna tal, Reykjavík: Hið íslenska bókmenntafélag, 2001, bls. 189-230; Ólafur Páll Jónsson, „Gagnrýnar manneskjur“, Hugur. Tímarit um heimspeki 2008, bls. 98-120; Guðmundur Heiðar Frímannsson, „Hugarfar gagnrýninnar hugsunar", Hugur. Tímarit um heimspeki, 2010, bls. 119-134; Eyja Margrét Brynjarsdóttir „Skynsemi eða rökleikni“ Skírnir 1/2013, bls. 55-79; Henry Alexander 
sem Páll lýsir hér virðist stangast á við pá hugmynd að við ættum að treysta sérfræðingum, til dæmis fyrir pví hvort loftslagsbreytingar séu af mannavöldum, pví raunverulegt traust með tilliti til tiltekinnar fullyrðingar virðist meðal annars fela í sér að maður telji sig ekki purfa að rannsaka hvað í fullyrðingunni felst eða finna fullnægjandi rök fyrir henni. Мeð öðrum orðum virðist traust fela í sér „útvistun“ á gagnrýninni hugsun til peirra sem við treystum, til dæmis til sérfræðinga, pannig að pað verði óparft og skemmi jafnvel fyrir ef við förum sjálf að hugsa gagnrýnið um efnið sem um er að ræða.

Рað hefur einmitt verið algengt, sérstaklega frá pví í fjármálahruninu árið 2008, að gagnrýna ýmsa aðila fyrir að reiða sig of mikið á álit annarra. Slík gagnrýni var sérlega áberandi pegar um var að ræða sérfræðinga sem voru sagðir treysta öðrum sérfræðingum gagnrýnislaust í stað pess að mynda sér sjálfir upplýsta skoðun. Eitt dæmi um petta er að finna í frægri skýrslu rannsóknarnefndar Alpingis, Aðdragandi og orsakir falls ílensku bankanna 2008 og tengdir atburðir. Í Viðauka I, „Siðferði og starfshættir í tengslum við fall íslensku bankanna 2008“ er fjallað um tiltekna skýrslu um stöðu bankanna sem tveir hagfræðingar, Frederic Mishkin og Tryggvi Pór Herbertsson, unnu fyrir Viðskiptaráð Íslands. Skýrslan birtist árið 2006, en á peim tíma var íslenskt fjármálakerfi orðið afar brothætt eins og alpjóð komst síðar að. Í skýrslu rannsóknarnefndarinnar segir meðal annars um pessa skýrslu:

Höfundarnir [Mishkin og Tryggvi Pór] lögðust ekki í sjálfsteða rannsókn á stöðu bankanna: „[V]ið skoðuðum bara matsskýrslurnar frá Moody’s og Fjármálaeftirlitinu og eitthvað slíkt." Mishkin og Tryggvi hafa uppi almenn viðvörunarorð um óvenjuhraðan vöxt banka, útlánaáhættu og krosseignatengsl, en ganga ekki úr skugga um hvort pau eigi við um íslenska hagkerfið á peim tíma sem skýrslan var skrifuð. [...] Höfundarnir taka gagnrýnislaust undir ábættumat Fjármálaeftirlitsins varðandi islensku bankana og segja að vegna pess að íslenskar ríkisstofnanir séu í háum gæðaflokki sé afar ólíklegt að alvarleg vandamál muni steðja að íslenska bankakerfinu. ${ }^{6}$

Henrysson og Páll Skúlason, Hugleiðingar um gagnrýna bugsun, Reykjavík: Heimspekistofnun - Háskólaútgáfan, 2014; Finnur Dellsén, „Gagnrýnin og vísindaleg hugsun“, Skirnir 2/2016, bls. 321-342; auk fjölmargra greina í bókinni Hugsað með Páli. Ritgerðir til heiðurs Páli Skúlasyni sextugum, ritstjórar Róbert H. Haraldsson, Salvör Nordal og Vilhjálmur Árnason, Reykjavík: Háskólaútgáfan, 2005.

6 Vilhjálmur Árnason, Salvör Nordal og Kristín Ástgeirsdóttir, „Viðauki I. Siðferði og starfshættir í tengslum við fall íslensku bankanna 2008“, Aðdragandi og orsakir falls islensku bankanna 2008 og tengdir atburðir, ritstjórar Páll Hreinsson, Sigríður Benediktsdóttir og Tryggvi Gunnarsson, Reykjavík: Rannsóknarnefnd Alpingis, 2010, 8. 
Gagnrýni rannsóknarnefndarinnar á skýrslu Mishkins og Tryggva Pórs mætti í raun orða pannig að peir hafi ranglega treyst Fjármálaeftirlitinu fyrir áhættumati á íslensku bönkunum. Í stað pess að treysta pessari stofnun, sem pó hefur á að skipa mörgum af helstu sérfræðingum landsins á pessu sviði, hafi peir átt að „leggjast í sjálfstæða rannsókn“ á stöðu bankanna.

Sú grunnhugmynd sem hér birtist - að pað sé eitthvað athugavert við að treysta orðum annarra og að fólk eigi fremur að mynda sér eigin skoðanir - á sér reyndar langa sögu. Líklega kom hún skýrast fram á tímum Upplýsingarinnar, frá og með sỉðari hluta sautjándu aldar og fram á pá nítjándu, með peirri uppreisn gegn kennivaldi sem Upplýsingunni fylgdi. Á pessum tíma urðu til dæmis til einkunnarorð Konunglega breska vísindafélagsins, „nullius in verba“, sem býdd hafa verið sem „tak ei mark á orðum einum“.? Heimspekingurinn John Locke virðist hafa verið sama sinnis pegar hann skrifaði: „Í pví felst engin pekking að láta skoðanir annarra flóta um í heilum

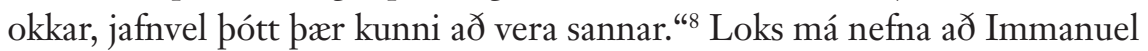
Kant skilgreindi beinlínis Upplýsinguna út frá peirri hvatningu að hugsa án handleiðslu annarra: „Upplýsing er lausn mannsins úr viðjum pess ósjálfreðis sem hann á sjálfur sök á. Ósjálfræði er vanhæfni mannsins til að nota eigið rökvit án handleiðslu annarra. [...] Einkunnarorð upplýsingarinnar eru pví „Sapere aude!“, hafðu hugrekki til að nota pitt eigið hyggjuvit!“"

Sú meginregla að fólk ætti að treysta sérfræðingum er pví bæði vandasöm í útfærslu, meðal annars vegna pess að við vitum ekki alltaf hvaða sérfræðingum við eigum að treysta, og svo virðist hún stangast á við pá algengu hugmynd að pað skipti máli að við myndum okkur sjálf skoðanir með gagnrýnum hætti. Engu að síður virðist mikilvægt og jafnvel nauðsynlegt að fólk treysti almennt sérfræðingum, eins og Guðni Elísson benti á. Pessi grein er tilraun mín til að leysa úr pessari togstreitu. Ég mun nálgast efnið með pví að velta pví fyrst fyrir mér hvað felst eiginlega í pví að bera traust til sérfreðinga. Ég mun freista pess að setja fram skilgreiningu á pessu fyrirbæri sem gerir okkur kleift að fjalla um pað af meiri nákvæmni en ella. Næst leita

bindi, bls. 214, skáletrun mín.

7 Ég hef fengið pessa prýðilegu pýðingu úr grein Guðmundar Magnússonar, „Ef kenning getur ekki verið röng, getur hún heldur ekki verið rétt“, Tíminn, 10. apríl 1983 , bls. 14 .

8 ,The floating of other men's opinions in our brains, makes us not one jot the more knowing, though they happen to be true." John Locke, An Essay Concerning Human Understanding, Oxford: Clarendon Press, 1975/1689, bók I, kafli iv, grein 23.

9 Immanuel Kant, „Svar við spurningunni. Hvað er upplýsing?“, pýðendur Elna Katrín Jónsdóttir og Anna Porsteinsdóttir, Skirnir 1993, bls. 379-386, hér bls. 379. 
ég svara við pví hvers vegna við verðum oft að treysta sérfræðingum frekar en að „nota eigið rökvit“, eins og Kant orðaði pað. Í stuttu máli er svarið einfaldlega að við höfum hvorki tíma né getu til að mynda okkur sjálf áreiðanlegar skoðanir á öllum málum sem við purfum að taka afstöðu til.

Í síðustu tveimur greinarköflunum sný ég mér svo að lykilspurningu pessarar greinar. Pessa spurningu mætti orða svona: Hvener eigum við að treysta sérfræðingum? Eins og spurningin er orðuð er hún vísvitandi tvíræð: Annars vegar gæti hún merkt: „Hvenær eigum við að treysta sérfræðingum frekar en að mynda okkur sjálf skoðanir?“ og hins vegar gæti hún merkt: „Að pví gefnu að við eigum að treysta einhverjum sérfræðingum, hvaða sérfræðingum eigum við pá að treysta?“ Ég hef spurninguna svona tvíræða vegna pess að ég hyggst svara báðum spurningunum. Svarið við seinni spurningunni er flókið en byggist í stuttu máli á að hafa ýmis viðmiðunaratriði til hliðsjónar pegar metið er hvort tiltekinn „sérfræðingur“ er traustsins verður. Svarið við fyrri spurningunni er að við eigum (aðeins) að treysta sérfræðingum pegar við erum ekki sjálf í aðstöðu til að vera eða gerast sérfræðingar um pað efni sem um er að ræða.

\section{Hvað er traust á sérfreðingum?}

Hvað felst í pví að treysta sérfræðingum? Til að auðvelda okkur að svara pessari spurningu má skipta henni í tvennt. Fyrri spurningin er pá: Hvað felst í að treysta einhverjum? Sú seinni er: Hvað er pað að vera sérfreðingur í einhverju? Við skulum byrja á seinni spurningunni.

Hér verður ekki gerð tilraun til að skilgreina hugtakið „sérfræðingur“ eins og pað er notað í öllu daglegu máli eða fyrir öll samhengi par sem orðið er notað. ${ }^{10}$ Tvennt einkennir hins vegar sérfræðinga af pví tagi sem ætla má að átt sé við pegar rætt er um traust á sérfræðingum. Mikilvægasta atriðið er að sérfræðingar hafa meiri pekkingu og hafni á tilteknu sérsviði miðað við tiltekinn hóp. Nánar tiltekið búa sérfræðingar yfir meiri upplýsingum í formi pekkingar á pessu sérsviði og eru par að auki áreiðanlegri pegar kemur að pví að meta nýjar upplýsingar og mynda sér skoðanir á pessu sviði. Ef sérfræðingarnir hafa meiri pekkingu og hæfni á sérsviðinu en fólk almennt pá getum við kallað pá algilda sérfreðinga. Ef sérfræðingarnir búa hins vegar aðeins yfir meiri bekkingu og hæfni á sérsviðinu en viðmelendur sínir, en eru verr settir eða á pari við fólk almennt, pá má kalla pá afsteða sérfreðinga. Sá

10 „Sérfræðingur“ er til dæmis orðið algengt starfsheiti en pað er ekki sú merking hugtaksins sem við höfum áhuga á í pessari grein. 
sem petta skrifar er til dæmis afstæður sérfræðingur í bílamálum pegar hann ræðir við sjö ára dóttur sína en langt frá pví að vera algildur sérfræðingur á pessu sviði. ${ }^{11}$

Hitt atriðið sem einkennir „sérfræðinga“ í peim skilningi orðsins sem ég mun einblína á í framhaldinu snýst um hvort peir geti gegnt hlutverki sínu sem sérfræðingar í pví samfélagi sem peir eru hluti af. Ímyndum okkur að peir sem hafa mestu pekkingu og hæfni á tilteknu sviði í ákveðnu samfélagi hafi engin sérstök áhrif á skoðanamyndun fólks í pessu samfélagi, til dæmis vegna mjög alvarlegra samskiptaörðugleika eða vegna pess að ekki er hlustað á pá frekar en aðra. Slíkir einstaklingar eru vissulega „sérfræðingar“ í ákveðnum skilningi orðsins, en í pessu samfélagi gegna peir ekki blutverki sínu sem sérfræðingar. ${ }^{12}$ Par sem ég mun einmitt fjalla um hvernig við eigum að treysta peim sem gegna slíku hlutverki pá væri ekki við hæfi í pessari grein að flokka viðkomandi til sérfræðinga á sviðinu. „Sérfræðingar“, í peim skilningi orðsins sem ég hef áhuga á, gegna pví ákveðnu hlutverki í samfélaginu sem gerir að verkum að pað er að minnsta kosti hægt að mynda sér skoðanir á grundvelli pess sem peir segja (hvort sem pað er nú í reynd gert eða ekki). Рað er sumsé ekki nóg að hafa mikla pekkingu og hæfni á sérsviði sínu til að vera sérfræðingur í peim skilningi sem hér er verið að skilgreina, heldur parf viðkomandi líka að geta verið einskonar „áhrifavaldur“ á sínu sérsviði.

Snúum okkur pá að hinni spurningunni: Hvað felst í pví að treysta einhverjum? Traust getur sjálfsagt verið af ýmsu tagi - til dæmis treystum við stundum fólki fyrir pví að gera eitthvað, svo sem að standa við gefin loforð eða haga sér sómasamlega á mannamótum. En petta er ekki sú tegund af trausti sem máli skiptir pegar kemur að trausti til sérfræðinga, pví pesskonar traust snýst ekki um að sérfræðingarnir grípi til tiltekinna aðgerða heldur snýst pað um að hægt sé að reiða sig á að pað sem peir segi sé satt og rétt. Pessi seinni tegund trausts snýst sumsé um hvernig við myndum okkar sannar eða réttar skoðanir með pví að hlusta á sérfræðinga. Мeð orðinu „skoðun“ á ég ekki bara við afstöðu fólks til umdeildra eða huglægra mála - samanber

11 Sá sem er afstæður sérfræðingur í pessum skilningi væri augljóslega ekki kallaður „sérfræðingur“ nema í mjög sérstökum kringumstæðum. Hugtakinu afsteður sérfreðingur er pví ekki ætlað að vera greining á hversdagslegri notkun á orðinu „sérfræðingur" heldur aðeins einskonar framlenging á hugtakinu algildur sérfreðingur.

12 Greinarmunurinn sem hér er gerður á að vera sérfræðingur og að gegna blutverki sérfræðings er ápekkur greinarmuni Olivers Scholz á blutlegum og buglegum sérfræðingum, sjá Oliver R Scholz, „Experts. What They Are and How We Recognize Them - A Discussion of Alvin Golman's Views“, Grazier Philosophishe Studies 2009, bls. $187-205$. 
viðkvæðið „petta er bara pín skoðun“ - heldur allt pað sem maður telur vera satt. Pannig er pað til dæmis bæði skoðun mín að kjötneysla sé siðferðilega óverjandi við núverandi aðstæður og að pað sé tölva beint fyrir framan nefið á mér. Skoðanamyndun, í pessum víða skilningi, er viðfangsefni pess undirsviðs heimspekinnar sem nefnist pekkingarfræði. Sú tegund af trausti sem við höfum áhuga á hér mætti pví kalla pekkingarfreðilegt traust.

Til að greina pekkingarfræðilegt traust aðeins nánar er gagnlegt að gera greinarmun á tvennskonar áhrifum sem annað fólk getur haft á pað hvernig við myndum okkur skoðanir um tiltekið efni. Annars vegar getur verið að önnur manneskja bendi okkur á rök eða gögn sem sannfæra okkur um að vera á tiltekinni skoðun. Petta má kalla óbein pekkingarfreðileg ábrif vegna pess að í svona tilvikum hefur hinn aðilinn áhrif á hvaða rökum eða gögnum við búum yfir, sem hefur svo aftur áhrif á pað hvernig við myndum okkur skoðanir. Раð sem hins vegar mætti kalla bein pekkingarfreðileg ábrifá skoðanamyndun er pað pegar við trúum einhverju í krafti pess eins að einhver annar segir að pað sé satt. Í pessum tilvikum sannfærumst við ekki af rökum eða gögnum viðkomandi, heldur tökum við orð viðkomandi einfaldlega trúanleg og myndum okkar svo skoðanir í samræmi við pau. ${ }^{13}$

Pessi greinarmunur á beinum og óbeinum pekkingarfræðilegum áhrifum er ekki gerður til að gera lítið úr annað hvort beinum eða óbeinum áhrifum. En pað getur skipt máli að átta sig á pví að um ólík fyrirbæri er að ræða. Pegar ég sest niður til að skrifa grein eins og pessa vonast ég fyrst og fremst til að sannfæra lesendur með rökum mínum fyrir pví sem ég held fram. Ég vil sem sagt hafa óbein áhrif á skoðanamyndun lesenda um tiltekið efni. En pegar ég fer svo heim og segi sjö ára dóttur minni að pað sé kominn háttatími pá vil ég hafa bein áhrif á skoðun hennar um hvort pað sé kominn háttatími hjá henni. Ef ég ruglast á pessu tvennu er hætt við að ég skrifi fræðigreinar par sem ég rökstyð ekki fullyrðingar mínar og lendi svo í tímafrekum rökræðum við dóttur mína um hvort tími sé kominn til að fara að sofa. Petta sýnir að greinarmunurinn á beinum og óbeinum áhrifum skiptir máli. ${ }^{14}$

13 Sjá frekari umræðu um pennan greinarmun í Finnur Dellsén, „The Epistemic Value of Expert Autonomy“, Philosophy and Phenomenological Research 2/2020, bls. 344-361, hér bls. 346-347. Sjá einnig Richard Foley, Intellectual Trust in Oneself and Others, Cambridge: Cambridge University Press, 2001, bls. 85.

14 Að vísu er greinarmunurinn ekki jafn klipptur og skorinn og halda mætti við fyrstu sýn. Í flestum eða jafnvel öllum tilvikum par sem einhver verður fyrir óbeinum pekkingarfræðilegum áhrifum verður viðkomandi einnig fyrir beinum pekkingarfræðilegum áhrifum. Ástæðan er sú að til að einn einstaklingur verði fyrir óbeinum pekkingarfræðilegum áhrifum frá öðrum einstaklingi parf sá fyrri að fá ný gögn eða 
Ég kýs að gera pennan greinarmun á beinum og óbeinum áhrifum á skoðanamyndun vegna pess að ég tel að pekkingarfreðilegt traust megi í grófum dráttum skilgreina sem pað samband sem er til staðar milli fólks pegar einn einstaklingur verður vísvitandi fyrir beinum pekkingarfræðilegum áhrifum frá öðrum einstaklingi. Ef maður treystir sérfræðingi á tilteknu sviði pá hneigist maður til að trúa pví sem hann segir um sitt sérsvið í krafti pess að hann segir pað. Меð öðrum orðum hefur sérfræðingurinn bein áhrif - eða í pað minnsta sterka tilhneigingu til að hafa bein áhrif - á skoðanamyndun manns á pessu sérsviði. Og ef maður treystir ekki pessum sérfræðingi pá hneigist maður ekki til að trúa pví sem viðkomandi segir í krafti pess að hann segir pað. Viðkomandi hefur pví ekki bein áhrif - eða ekki sterka tilhneigingu til að hafa bein áhrif - á skoðanamyndun manns á pessu sérsviði. Til dæmis væri ekki um sannkallað traust að ræða ef maður væri aðeins tilbúinn að trúa pví sem sérfræðingur segði að pví gefnu að hann miðlaði til manns rökum eða gögnum sem sannfæra mann um að hann hafi rétt fyrir sér, enda væri maður pá í raun að sannfærast af rökunum sjálfum en ekki af peim sem setur pau fram. ${ }^{15}$

Rétt er pó að taka fram að gögn og rök geta gegnt mjög mikilvægu hlutverki í pví að skapa traust til sérfræðinga. Við fyrstu kynni af tilteknum sérfræðingi sem við höfum litla ástæðu til að treysta fyrirfram - til dæmis vegna pess að við kunnum ekki skil á peirri stofnun sem viðkomandi segist vinna hjá eða sökum pess að við höfum aldrei heyrt um sérsviðið - pá er eðlilegt að trúa viðkomandi aðeins ef hann eða hún virðist hafa rök eða gögn til að styðja mál sitt. Ef pað sem viðkomandi segir reynist svo almennt vera satt, pá

rök frá peim síðari, og pessi miðlun gagna eða raka fellur væntanlega undir bein pekkingarfræðileg áhrif. Greinarmunurinn á beinum og óbeinum pekkingarfræðilegum áhrifum fellur pó ekki saman pví beinu og óbeinu áhrifin snúa að ólíkum hlutum: beinu áhrifin snúa að gögnunum eða rökunum fyrir tiltekinni afstöðu, en óbeinu áhrifin snúa að afstöðunni sjálfri sem gögnin eða rökin eiga að styðja eða grafa undan.

15 Pessi skilgreining á pekkingarfræðilegu trausti er ápekk skilgreiningu Thi C. Nguyen, "Trust as an Unquestioning Attitude“, Oxford Studies in Epistemology, Oxford: Oxford University Press (í birtingu). Eins og Nguyen bendir réttilega á má leggja ólíkan skilning í orð eins og „traust“ og engin ástæða til að ætla að hægt sé - eða æskilegt - að gefa orðinu aðeins eina tiltekna merkingu. Dæmi um annars konar skilgreiningar á trausti má til dæmis finna hjá Annette Baier, „Trust and Antitrust“, Ethics 2/1986, bls. 231-260; Karen Jones, "Trust as an Affective Attitude“, Ethics 1/1996, bls. 4-25; Onora O'Neill, Autonomy and Trust in Bioethics, Cambridge: Cambridge University Press, 2002; Paul Faulkner, „A Geneology of Trust“, Episteme 3/2007, bls. 305-321. 
byggist hægt og bítandi upp traust til hans sem gerir að verkum að við sjáum okkur fært að trúa honum jafnvel í peim tilfellum sem hann vísar ekki í gögn eða rök máli sínu til stuðnings. Ef við rekumst hins vegar á „sérfræðing“ sem setur aldrei fram gögn til að undirbyggja fullyrðingar sínar, og neitar að færa rök fyrir máli sínu, pá fer okkur eðlilega að gruna að viðkomandi geti ekki reitt fram slík gögn eða rök. Afleiðingin er pá sú að pað byggist ekki upp traust til einstaklingsins og við trúum honum eða henni pví ekki nema viðkomandi geti einmitt sett fram sannfærandi gögn eða rök máli sínu til stuðnings í hvert skipti sem hann tjáir sig.

Petta breytir pví ekki að pegar pekkingarfræðilegt traust er (loks) til staðar felur pað í sér að sá sem treystir er tilbúinn að trúa peim sem er treyst án pess að sá síðarnefndi purfi að reiða fram gögn eða rök máli sínu til stuðnings - að minnsta kosti með tilliti til pess álitamáls sem um er að ræða. Í stuttu máli má pví kannski segja að traust sé pað samband sem ríkir milli fólks pegar rök og gögn verða ópörf. Ég held pví að við getum svarað spurningunni um hvað felist í pví að treysta sérfræðingum með verklegri skilgreiningu (e. operational definition) sem hljómar svona: Einstaklingur ber traust til sérfræðings pá og pví aðeins að sérfræðingurinn hafi - eða hafi sterka tilhneigingu til að hafa - bein áhrif á skoðanamyndun einstaklingsins á sérsviði sérfræðingsins. Pessi skilgreining lýsir kannski ekki innsta eðli trausts til sérfræðinga eða hvernig manni líður pegar maður treystir sérfræðingi, en ég held að hún fangi vel pað sem máli skiptir pegar við förum að velta fyrir okkur spurningum eins og bvaða sérfræðingum við eigum að treysta og bvers vegna við eigum að treysta peim. Мeð öðrum orðum held ég að pessi skilgreining geri pað gagn sem henni er ætlað að gera í pessari grein.

\section{Hvers vegna að treysta sérfreðingum?}

Með petta svar við pví hvað felist í pví að treysta sérfræðingum í farteskinu getum við nú snúið okkur að næstu spurningu: Hvers vegna ættum við að treysta sérfræðingum yfirleitt? Í stað pess að treysta sérfræðingum gætum við kosið að nálgast ummæli peirra af varúð og skoða rök peirra gaumgæfilega í hvert skipti með pað að markmiði að mynda okkur sjálf skoðanir á pví hvort viðkomandi hafi á réttu að standa. Pá værum við að leyfa sérfræðingum að hafa óbein áhrif á skoðanamyndun okkar. Spurningin er sumsé hvers vegna við ættum að leyfa sérfræðingum að hafa bein áhrif á skoðanamyndun okkar en ekki bara óbein áhrif.

Til að svara pessu held ég að gagnlegt sé að skoða ákveðna hugmynd um 
vísindamiðlun sem gerir $e k k i$ ráð fyrir pví að almenningur treysti sérfræðingum um pau vísindi sem um er að ræða. Pessi hugmynd kallast vöntunarlikanið um vísindamiðlun (e. the deficit model of science communication). Vöntunarlíkanið kveður á um að efasemdir og ranghugmyndir fólks um vísindi megi einfaldlega rekja til pess að pað hafi ekki nægilega miklar upplýsingar. Almenning skorti pekkingu bæði á vísindum almennt, starfsemi peirra og aðferðafræði, og eins á viðteknum vísindakenningum, tilteknum vísindarannsóknum og helstu niðurstöðum peirra. Ef almenningur vissi hvernig vísindin virka í raun og hvað pau hafa komist að niðurstöðu um, pá myndi fólk leggja meiri trúnað á réttar og haldbærar rannsóknarniðurstöður og minni trúnað á falsvísindi og annað fúsk sem sagt er byggjast á vísindalegum rannsóknum. Рað sem purfi til sé pví einfaldlega betra eða meira upplýsingaflæði frá vísindafólki til almennings, til dæmis í gegnum menntakerfið, fjölmiðla og aðrar opinberar stofnanir. ${ }^{16}$

Sú hugmynd að mikilvægt sé að almenningur viti meira um helstu vísindaniðurstöður og hvernig vísindastarf fer fram í raun og veru er góðra gjalda verð. Pó bendir fátt til pess að hægt sé að koma í veg fyrir að almenningur hafi efasemdir og ýmsar ranghugmyndir um vísindalegar kenningar með pví einu að veita meiri upplýsingum til almennings. Fyrir pessu eru fyrst og fremst tvær ástæður. Annars vegar benda rannsóknir pví miður ekki til pess að aukið upplýsingaflæði leiðrétti vísindalegar ranghugmyndir eða fái fólk til að hætta að efast um vel rökstuddar vísindakenningar. Pess í stað benda rannsóknir til pess að eftir pví sem fólk verður betur upplýst um vísindi pá myndi pað sér einfaldlega meira afgerandi skoðanir á umdeildum vísindakenningum. Peir sem efast til dæmis um loftslagsbreytingar verða enn vissari í sinni sök eftir að hafa meðtekið upplýsingarnar. ${ }^{17}$ Líklega má skýra petta með einskonar staðfestingarskekkju (e. confirmation bias) par sem fólk velur úr pær upplýsingar sem henta fyrirframgefnum skoðunum peirra en horfir fram hjá öðrum sem gera pað ekki. ${ }^{18}$

16 Segja má að vöntunarlíkanið sé tilraun til að lýsa algengri - en jafnan óorðaðri - skoðun meðal vísindafólks um hvernig best sé að efla vísindalæsi og skilning á vísindum. Sjá meðal annars Brian Wynne, „Public Understanding of Science Research. New Horizons of Hall of Mirrors?", Public Understanding of Science 1/1992, bls. 37-43.

17 Dan M. Kahan og fleiri, „The polarizing impact of science literacy and numeracy on perceived climate change risks“, Nature Climate Change 2/2012, bls. 732-735; Caitlin Drummond og Baruch Fischhoff, „Individuals with greater science literacy and education have more polarized beliefs on controversial science topics“, $P N A S$ 36/2017, bls. 9587-9592.

18 Raymond S. Nickerson, „Confirmation Bias. A Ubiquitous Phenomenon in Many 
Annað vandamál er að eftir pví sem magn upplýsinga eykst - par á meðal um vísindi og vísindalegar niðurstöður - verður sífellt óraunhæfara að ætlast til pess að nokkur einstaklingur geti verið vel upplýstur um öll vísindi sem snerta hans daglega líf. ${ }^{19}$ Jafnvel pótt maður gerði ekkert annað en að kynna sér nýjustu vísindarannsóknir á ólíkum sviðum pá tækist manni tæpast að mynda sér sjálfur upplýsta skoðun á hverri einustu rannsókn - nema pá hugsanlega með pví að treysta sérfræðingunum á hverju sviði fyrir pví að rannsóknirnar séu einfaldlega réttar (meira um pað síðar). Vísindin sjálf og starfsemi peirra eru að sama skapi sífellt að verða viðameiri og flóknari og peir fáir til sem hafa mikla yfirsýn um hvernig vísindarannsóknir fara fram í ólíkum greinum vísinda. ${ }^{20}$ Sú kenning að okkur vanti aðeins meiri upplýsingar til að leiðrétta ranghugmyndir og vinna gegn órökréttum efasemdum er pví í stuttu máli sagt óraunhæf og verður sífellt óraunhæfari með hverjum degi sem líður.

Ég held að pessi tvö rök gegn vöntunarlíkaninu um vísindamiðlun varpi ágætu ljósi á pað hvers vegna traust á sérfræðingum er mikilvægt og reyndar óhjákvæmilegt í nútíma samfélögum. Í fyrra lagi er mikilvægt að treysta sérfræðingum pví að geta okkar til pess að taka upplýstar ákvarðanir um flókin mál er oft afar takmörkuð - og ekki bætir úr skák að við höfum ríka tilhneigingu til að ofmeta pessa getu. ${ }^{21}$ Í seinna lagi er brýnt - eða óhjákvæmilegt - að treysta sérfræðingum vegna pess að við höfum einfaldlega ekki ráðrúm til að mynda okkur upplýstar skoðanir sjálf um öll málefni milli himins og jarðar, heldur purfum við að „útvista“ pessa skoðanamyndun til annarra aðila sem við höfum ástæðu til að telja líklega til að komast að réttri niðurstöðu. Í stuttu máli er svarið við spurningunni hvers vegna við eigum að treysta sérfræðingum einfaldlega pað að við höfum ekkert val - að minnsta kosti ekki að svo miklu leyti sem við viljum að skoðanir okkar endurspegli raunveruleikann.

Guises“, Review of General Psychology 2/1998, bls. 175-220.

19 Sem dæmi má nefna að sé leitarstrengurinn „COVID-19“ sleginn inn í GoogleScbolar koma nú pegar upp 136 púsund aðskildar færslur pegar petta er skrifað (7. júní 2020).

20 Nema kannski helst peir sem hafa af pví atvinnu, svo sem vísindaheimspekingar, vísindasagnfræðingar og vísindafélagsfræðingar. Flestir sem falla undir pessa hópa sérhæfa sig pó í einhverjum tilteknum vísindagreinum eða -sviðum en fjalla sjaldnar um vísindin í heild sinni.

21 Justin Kruger og David Dunning, „Unskilled and Unaware of It. How Difficulties in Recognizing One's Own Incompetence Lead to Inflated Self-Assessments“, Fournal of Personality and Social Psychology 6/1999, bls. 1121-1134. 
Petta gildir reyndar ekki bara um pá sem eru neytendur sérfræðipekkingar heldur líka um pá sem skapa sérfræðipekkinguna, til dæmis vísindafólk. Eins og bent hefur verið á byggist vísindastarf líka á trausti til sérfræðinga - til dæmis á trausti á milli meðhöfunda með ólík sérsvið sem vinna saman að fræðilegri grein á mörkum sinna sérsviða. ${ }^{22}$ Fræðilegir eðlisfræðingar treysta til dæmis gögnum frá tilraunaeðlisfræðingum og sönnunum frá stærðfræðingum, leiðbeinendur treysta doktorsnemunum sínum fyrir pví að hafa aflað gagnanna í sameiginlegri rannsókn með samviskusamlegum hætti, ritrýnar í tilraunavísindum treysta höfundum fyrir pví að hafa raunverulega framkvæmt tilraunina sem peir segjast hafa framkvæmt og svo framvegis. Án pessa trausts væri í raun ekki hægt að ástunda vísindi eins og við pekkjum pau nú til dags. Traust til sérfræðinga er pví ekki aðeins mikilvægt í samskiptum sérfræðinga og almennings heldur líka í samskiptum sérfræðinga sín á milli pegar peir skapa nýja pekkingu.

\section{Hvenar eigum við að treysta sérfreðingum?}

Ég hef nú fært rök fyrir pví að í mörgum tilvikum sé óhjákvæmilegt að treysta sérfræðingum, að minnsta kosti fyrir pá sem ætla sér að mynda sér sannar eða sennilegar skoðanir. En petta vekur strax upp nýjar spurningar: Hvaða sérfræðingum eigum við pá að treysta, og í hvaða kringumstæðum eigum við að treysta peim? Petta eru flóknar spurningar sem ekki er hægt að svara með einhlítum hætti en í pessum hluta ætla ég samt sem áður að benda á ýmis atriði sem við ættum að hafa í huga pegar við glímum við spurningar af pessu tagi. Í næsta hluta mun ég svo snúa mér að nátengdri spurningu: Hvenær eigum við ekki að treysta sérfræðingum, jafnvel pótt peir séu traustsins verðir, og í staðinn reyna að komast sjálf að niðurstöðu um efnið sem um er að ræða?

En byrjum á fyrri spurningunum tveimur: Hvaða sérfræðingum eigum við að treysta, og í hvaða kringumstæðum? Til að svara henni er gagnlegt að byrja á pví að minna okkur á að við erum stöðugt að greina pá sem við teljum okkur geta treyst frá peim sem við teljum okkur purfa að vantreysta. Við treystum til dæmis yfirleitt fólki sem við höfum bekkt í nokkurn tíma að minnsta kosti ef viðkomandi hefur ekki brugðist trausti okkar áður - en vantreystum oft peim sem við höfum aldrei hitt áður. Við treystum tölvu-

22 Finnur Dellsén, „Gagnrýnin og vísindaleg hugsun“, Skírnir 1/2016, bls. 85-106, hér bls. 101-102; John Hardwig, „Epistemic Dependence“, Fournal of Philosophy 7/1985, bls. 335-349, hér bls. 338-339. 
pósti frá fólki og stofnunum sem við könnumst við eða hljóma kunnuglega en vantreystum skilaboðum frá fólki sem við höfum aldrei heyrt getið og eru skrifuð á máli sem ætla má að komi beint úr býðingarvél. Svona mætti lengi telja.

Pegar við drögum fólk og skilaboð í dilka með pessum hætti erum við vitaskuld ekki að ástunda nákvæm vísindi. Рað eru engar algildar reglur um hvenær eigi að treysta öðrum og hvenær ekki. Á hinn bóginn er pessi flokkun ekki heldur handahófskennd, sem sést best á pví að ólíkir einstaklingar komast oft að mjög svipuðum niðurstöðum um pað hverjum sé treystandi og hverjum ekki. Рað bendir til pess að pað sé að minnsta kosti hægt að grafast fyrir um hvaða pættir pað eru sem almennt séð hafa áhrif á pað hverja við teljum traustsins verða. Og ef okkur tekst að gera pað pá getum við líka tekist á við spurningu eins og hvaða pættir eigi að hafa áhrif á pað hverjum við treystum. Til dæmis er vel pekkt að fordómar og skekkjur - sem oft eru ómeðvitaðar eða duldar - hafa oft mikil áhrif á pað hverjum við kjósum að treysta. $^{23}$

Spurningar af pessu tagi eru meðal peirra sem fengist er við í pví undirsviði pekkingarfræðinnar sem kallast félagspekkingarfreði (e. social epistemology). Ég ætla pví að leita í smiðju félagspekkingarfræðinnar til að leitast við að svara pví hvaða sérfræðingum við eigum að treysta og í hvaða kringumstæðum. Ég mun einnig leita fanga í vísindaheimspeki, par á meðal feminiskri vísindaheimspeki, par sem spurningar sem eru nátengdar félagspekkingarfræði hafa lengi verið til umræðu. Мeð pví að höfða til niðurstaðna úr pessum fræðasviðum mun ég freista pess að setja fram einskonar gátlista af páttum sem ættu að hafa áhrif á pað hvaða sérfræðingum við treystum.

Ég kalla pennan gátlista félagspekkingarfreðilega verkferakassann. Ég kýs að kalla petta „verkfærakassa“ vegna pess að ég lít á atriðin á listanum sem einskonar viðmiðunaratriði sem við getum notað til að átta okkur á pví hverjum við eigum að treysta, fremur en sem lista af nauðsynlegum og nægjanlegum skilyrðum fyrir pví að treysta einhverjum. (Til samlíkingar má segja að pessi atriði séu eins og listi af sjúkdómseinkennum sem læknar nota til að greina tiltekinn sjúkdóm. Sjúklingarnir eru sjaldnast með nema hluta peirra einkenna sem á listanum eru og hægt er að hafa misalvarleg einkenni af hverju tagi.) Раð væri sennilega vel hægt að setja fram nauðsynleg og

23 Sjá til dæmis Miranda Fricker, Epistemice Injustice. Power and the Ethics of Knowing, Oxford: Oxford University Press, 2007. Fyrsti kafli bókarinnar hefur birst á íslensku: Miranda Fricker, „Vitnisburðarranglæti“, býðandi Egill Arnarson, Hugur. Timarit um heimspeki 2018, bls. 15-29. 
nægjanleg skilyrði fyrir trausti á sérfræðingum, eins og heimspekingum er tamt að gera, en ég hef ekki trú á að hægt sé að setja fram skilyrði af pessu tagi sem við yrðum í aðstöðu til að meta hvort uppfyllt séu. ${ }^{24}$ Ef við viljum setja fram lista af atriðum sem eitthvert gagn er að pá purfum við að sætta okkur við að pessi atriði séu líkari viðmiðunaratriðum - eða verkfærum heldur en nauðsynlegum og nægjanlegum skilyrðum.

Fyrsta atriðið á listanum - fyrsta verkfærið sem ég tel að við ættum að notast við - snýst um hvort sérfræðingarnir sem um er að ræða séu nægilega margir og hvort peir séu nokkurn veginn á sama máli. Í stuttu máli má segja að við ættum að horfa til samsetningar sérfræðinganna. Pví miður hættir okkur oft til að hlusta á tiltekna sérfræðinga sem segja okkur sitt einstaklingsbundna álit á tilteknu álitamáli. Petta getur verið hættulegt pví ef viðkomandi sérfræðingur er á skjön við meirihluta annarra sérfræðinga á sínu sviði, pá er mun áreiðanlegra að treysta á pað sem almenn samstaða er um á meðal flestra sérfræðinga á viðkomandi sviði. Einstaka sérfræðingar geta hæglega haft rangt fyrir sér - enda eru sérfræðingar bara mannlegir - en pegar nægilega margir peirra komast að svipaðri niðurstöðu verða líkurnar á að hún sé röng hverfandi litlar. ${ }^{25}$

Reyndar má færa rök fyrir pví að jafnvel pegar kemur að alöruggustu niðurstöðum vísinda megi jafnan búast við pví að hægt sé að finna einstaka sérfræðinga sem eru ósammála niðurstöðunni. Heilbrigt vísindastarf byggist að miklu leyti á pví að gagnrýni og efasemdir um framkomnar kenningar, niðurstöður og ályktanir séu ekki bældar niður heldur sé efasemdum svarað og gagnrýni tekin til greina. Рað er pví í raun ákveðið hættumerki frá sjónarhóli peirra sem standa utan tiltekins sérfræðisviðs ef allir sérfræðingar eru á einu máli um fullyrðingu eða kenningu sem ætla má að erfitt sé að meta

24 Til dæmis mætti segja að við ættum einfaldlega að treysta sérfræðingum sem eru í reynd áreiðanlegir. Nauðsynlegt og nægjanlegt skilyrði fyrir trausti er pví áreiðanleiki. Vandinn við pessa tillögu er hins vegar að við vitum sjaldnast hvort tiltekinn sérfræðingur er áreiðanlegur og pví er oft lítið gagn að pví að vera sagt að treysta sérfræðingum sem eru í reynd áreiðanlegir.

25 Petta er meðal ályktana sem draga má af kviðdómssetningu Condorcet, sem kennd er við franska fjölfræðinginn Nicolas de Condorcet (1743-1794). Í stuttu máli kveður setningin á um að ef hver einasti einstaklingur í tilteknum hópi er líklegri en ekki til að hafa rétt fyrir sér (eins og sérfræðingar eru væntanlega), pá aukast líkurnar á að meirihlutinn hafi rétt fyrir sér eftir pví sem hópurinn stækkar. Pví má álykta að almennt sé meiri ástæða til að treysta meirihluta sérfræðinga eftir pví sem sérfræðingarnir eru fleiri. Nánar má lesa um beitingu kviðdómssetningarinnar í pessu samhengi hjá David Estlund, „Opinion Leaders, Independence, and Condorcet's Jury Theorem“, Theory and Decision 2/1994, bls. 131-162. 
með áreiðanlegum hætti á grundvelli peirra gagna sem fyrir liggja. ${ }^{26}$ Sú staðreynd að til séu sérfræðingar sem eru ósammála meirihlutaskoðuninni ætti pví almennt séð ekki að draga úr tiltrú okkar á að meirihlutaskoðunin sé rétt ef meirihlutinn er engu að síður mjög stór. Af pessu leiðir að pað er vægast sagt villandi pegar fjölmiðlar draga fram sérfræðinga sem eru í algjörum minnihluta á sínu sviði til að vega upp á móti pví að tala við sérfræðinga sem eru á meirihlutaskoðuninni.

Annað atriði sem rétt er að taka mið af pegar meta skal traust sérfræðinga er pað sem kalla mætti fyrri reynslu okkar af viðkomandi sérfræðingum. Til að beita pessu verkfæri spyrjum við okkur hvort sérfræðingarnir hafi áður reynst hafa á réttu að standa um sambærileg álitamál. Við getum spurt pessarar spurningar um einstaka sérfræðinga, pað er að segja hvort tiltekinn sérfræðingur hafi haft á réttu að standa um svipuð efni. En við getum líka spurt sömu spurningar um hópa af sérfræðingum og jafnvel um stofnanir sem sérfræðingarnir starfa hjá. Auk pess getum við spurt pessarar spurningar um sérfræðisviðið í heild sinni, pað er að segja hvort sérfræðingar á viðkomandi sviði hafi áður haft rétt fyrir sér. Við höfum meiri ástæðu til að treysta sérfræðingum sem hafa reynst hafa rétt fyrir sér áður, ekki endilega vegna pess að peir séu í eðli sínu skynsamari en aðrir heldur til dæmis vegna pess að peir sérfræðingar sem hafa haft á réttu að standa áður eru líklegri til að fullyrða aðeins um pað sem peir raunverulega vita með vissu. ${ }^{27}$

Á sumum sérfræðisviðum virðumst við geta fullyrt að pað sem sérfræðingar hafi áður haldið fram hafi reynst vera rétt. Til dæmis er afar sjaldgæft að sannanir stærðfræðinga séu dregnar til baka eftir að pær hafa verið yfirfarnar af öðrum stærðfræðingum. Аð sama skapi er sjaldgæft að viðteknum hugmyndum í eðlisfræði sé algjörlega varpað fyrir róða en pó hafa ýmsar eðlisfræðikenningar verið sampykktar fyrr á tímum sem nú eru taldar fjarri sannleikanum - svo sem ljósvakakenningin um bylgjuhreyfingu ljóss og flógistonkenningin um bruna. ${ }^{28}$ Á öðrum sérfræðisviðum virðist vera nokkuð algengt að fyrri kenningum sé hafnað með öllu. Pessi misserin eru

26 Sjá Finnur Dellsén, „Consensus and Marginal Dissent. A Social Epistemology for the $97 \%$ ", óbirt handrit.

27 Um petta atriði má lesa í umræðum vísindaheimspekinga um pað hvaða ályktanir beri að draga af fyrri reynslu okkar af tilteknum vísindagreinum og -kenningum. Sjá til dæmis Larry Laudan, „A Confutation of Convergent Realism“, Philosophy of Science 1/1981, bls. 19-49; Marc Lange, „Baseball, Pessimistic Inductions and the Turnover Fallacy“, Analysis 276/2002, bls. 281-285; Ludwig Fahrbach, „How the Growth of Science Ends Theory Change“, Synthese 2/2011, bls. 139-155.

28 Sjá til dæmis Larry Laudan, „A Confutation of Convergent Realism“, bls. 33. 
til dæmis miklar umræður um hvort treysta beri niðurstöðum ýmissa fræðigreina, svo sem í félags- og heilbrigðisvísindum, par sem reynst hefur erfitt að fá sömu rannsóknarniðurstöður og áður pegar tilraun úr birtri vísindagrein er endurtekin. ${ }^{29}$

Priðja atriðið sem ég tel rétt að taka mið af snýst um hvort tiltekin fjölbreytni sé til staðar meðal sérfræðinganna. Nánar tiltekið purfum við að spyrja okkur hvort sérfræðingarnir séu allir eins hvað varðar aðferðafræði og bakgrunnspekkingu, eða hvort peir komi úr ólíkum áttum að pessu leyti. Ef sérfræðingar komast að sömu niðurstöðu prátt fyrir að beita ólíkum aðferðum og styðjast við ólíka bakgrunnspekkingu pá er líklegra en ella að peir hafi á réttu að standa. Rökin fyrir pessu eru hliðstæð rökunum fyrir pví að pað er betri prófsteinn á tilgátu pegar tvær ólíkar tilraunir eru gerðar til að prófa tilgátuna en að gera sömu tilraunina tvisvar. ${ }^{30}$ Með hliðstæðum hætti er pað betri mælikvarði á áreiðanleika fullyrðingar að sérfræðingar úr ólíkum áttum skuli vera sammála um að fullyrðingin sé sönn en pegar sérfræðingarnir sem eru sammála um kenninguna notast við sömu aðferðafræði og byggja mat sitt á samskonar bakgrunnspekkingu. ${ }^{31}$

Ástæðan fyrir bessu er í grófum dráttum sú að ef sérfræðingarnir sem um er að ræða koma úr ólíkum áttum er ólíklegra að peir geri sömu mistökin í mati sínu á sanngildi fullyrðingarinnar. Til dæmis eru minni líkur á að sérfræðingar úr ólíkum áttum byggi niðurstöðu sína á sömu ósönnu forsendunni og gerist sekir um sömu hugsanaskekkju. Pótt pessir sérfræðingar séu ef til vill jafn líklegir og aðrir til að gera einbver mistök pá er ólíklegra að peir geri sömu mistökin. Af pví leiðir svo að peir eru ólíklegri til að komast að sömu niðurstöðu nema sú niðurstaða sé i reynd sönn samanborið við sérfræðinga sem beita sömu aðferðum og styðjast við sömu bakgrunnspekkingu. Peir sem koma úr sömu áttinni eru með öðrum orðum líklegri til að komast að sömu niðurstöðu óháð pví hvort sú niðurstaða sé sönn. Af pessu

29 Talað er um að pessar vísindagreinar standi frammi fyrir endurtekningarvanda (e. replication crisis). Sjá til dæmis C. Glenn Begley og Lee M. Ellis, „Raise standards for preclinical cancer research“, Nature 2012, bls. 531-533; Open Science Collaboration, „Estimating the reproducibility of psychological science“, Science 6251/2015, aac4716.

30 Á ensku nefnist petta fyrirbæri „consilience“, sjá William Whewell, Novum Organum Renovatum, 3. útgáfa, London: John W. Parker and Son, 1858.

31 Finnur Dellsén, „The Epistemic Value of Expert Autonomy“, bls. 351-358 og „When Expert Disagreement Supports the Consensus“, Australasian Fournal of Philosophy 1/2018, bls. 142-156. 
leiðir að pað er betri vísbending um að tiltekin niðurstaða sé sönn pegar sérfræðingar sem fullyrða að svo sé koma úr ólíkum áttum. ${ }^{32}$

Rétt er að nefna að að svo miklu leyti sem bakgrunnspekking og jafnvel aðferðafræði sérfræðinga ræðst af félagslegum bakgrunni peirra og persónulegri reynslu pá skiptir máli að sérfræðingarnir sem við treystum séu ekki allir eins hvað pað varðar. Рað getur til dæmis verið mikilvægt að peir sem um er að ræða séu ekki allir úr sömu stétt, af sama kyni, flokkist í sama „kynpátt“ og svo framvegis. Petta skiptir vitaskuld mismiklu máli eftir pví hversu líklegt má telja að sú bakgrunnspekking sem pættir af pessu tagi hafa áhrif á sé einnig pesskonar bakgrunnspekking sem stuðst er við á viðkomandi sérsviði. Petta er ein mikilvæg ástæða pess að pað væri til dæmis óráð að setja saman sérfræðinefnd um fátækt sem samanstæði aðeins af fulltrúum sem sjálfir teljast vera í há- og millistétt.

Síðasta atriðið sem ég tel rétt að hafa í huga við mat á pví hvaða sérfræðingum við ættum að treysta er líklega pað vandasamasta. Раð snýr að pví hvaða bvata sérfræðingarnir hafa til að komast að tiltekinni niðurstöðu eða setja fram tiltekna fullyrðingu. Til að beita pessu verkfæri purfum við að spyrja okkur hvort tilteknir sérfræðingar miði beint eða óbeint að pví að upplýsa um hvað sé satt fremur en til dæmis hvað peir eða vinnuveitendur peirra hagnast mest á að fullyrða. Sumum „sérfræðingum“ fyrirtækja er til dæmis borgað sérstaklega fyrir að komast að niðurstöðu sem hentar vinnuveitendum peirra, og pá er vitaskuld lítið hægt að treysta viðkomandi sérfræðingum. ${ }^{33}$ Petta er hins vegar vandasamt verkfæri vegna pess að við hugsum öll eða flestöll um eigin hag að einhverju leyti en pað á við um sérfræðinga líkt og alla aðra. Á hinn bóginn eru sum svið mannlegrar tilveru pannig að peir hvatar sem til staðar eru á sviðinu miða að pví að sannleikurinn komi fram og ósannindi verði hægt og bítandi leiðrétt. ${ }^{34}$

Jafningjamatskerfinu í vísindum og fræðum er til dæmis ætlað að stuðla að áreiðanleika vísindalegra niðurstaðna með pví að láta vísindafólk sem á

32 Sjá einnig Lu Hong og Scott E. Page, „Groups of diverse problem solvers can outperform groups of high-ability problem solvers“, PNAS 24/2014, bls. 16385-16389.

33 Sjá til dæmis Naomi Oreskes og Eric M. Conway, Merchants of Doubt, New York: Bloomsbury, 2010, bls. 20-23 (um tóbaksiðnaðinn). Eins og Oreskes og Conway benda á hefur pessu verið beitt markvisst til að skapa efasemdir um að reykingar valdi lungnakrabbameini og að losun gróðurhúsalofttegunda valdi loftslagsbreytingum.

34 Sjá til dæmis Bennett Holman og Kevin C. Elliot, „The Promise and Perils of Industry-Funded Research“, Philosophy Compass 13: 11/2018, bls. e12544. 
ekki beinan hag að pví að tiltekið efni sé birt fara yfir rannsóknir annars vísindafólks. Рað er höfundum í hag að rannsóknir peirra séu birtar, meðal annars vegna pess að birtar rannsóknir tryggja peim störf og launahækkanir, en peir sem fara yfir vísindagreinar annarra (ritrýnar og ritstjórar tímarita) hafa sjaldan beinan hag af pví að sampykkja pær. Petta kerfi kemur pannig í veg fyrir að vísindafólk geti birt hvaða rugl sem er í vísindatímaritum, pótt auðvitað komi líka fyrir að rangar eða falsaðar rannsóknir birtist í virtum vísindatímaritum. ${ }^{35}$ Til samanburðar má nefna að ekki eru samskonar kerfi til staðar hjá ýmsum einkaaðilum sem veita „ráðgjöf“ til fyrirtækja og einstaklinga.

Pau fjögur atriði sem hér hafa verið nefnd - samsetning, fyrri reynsla, fjölbreytni og bvatar - eru sumsé pau „verkfæri“ sem rannsóknir í félagspekkingarfræði og vísindaheimspeki benda til að megi nota sem verkfæri til að meta hvort sérfræðingar séu traustsins verðir. Eins og áður segir eru pessir pættir hvorki nauðsynleg skilyrði hver í sínu lagi, né eru peir allir saman nægjanlegt skilyrði, heldur eru peir líkari vísbendingum um hvort treysta beri viðkomandi sérfræðingum. Eflaust mætti líka tína til fleiri pætti af pessu tagi, svo sem hvort sérfræðingarnir hafi sampykkt viðkomandi kenningu eða fullyrðingu í lengri eða styttri tíma. ${ }^{36}$ En ég ætla að láta petta duga hér. Í staðinn ætla ég að snúa mér að annarri spurningu: Eru til kringumstæður par sem við eigum ekki að treysta sérfræðingum - jafnvel pótt viðkomandi sérfræðingar séu traustsins verðir frá okkar bæjardyrum séð?

\section{Að bugsa út fyrir verkferakassann}

Í 3. hluta færði ég rök fyrir pví að pað sé oft mikilvægt og reyndar nauðsynlegt að treysta sérfræðingum pví oft höfum við hvorki tíma né getu til að mynda okkur áreiðanlegar skoðanir. Petta býðir hins vegar ekki að við ættum alltaf að mynda okkur skoðanir með pví að vísa til sérfræðinga - að

35 Sem dæmi um pað má nefna grein Andrews Wakefields og fleiri, „Ileal-lymphoidnodular hyperplasia, non-specific colitis, and pervasive developmental disorder in children“, sem birtist upphaflega í læknatímaritinu The Lancet árið 1998 en var svo dregin til baka vegna ýmissa falsana og rangfærslna sem í greininni voru. Greinin er talin vera ein af lykilástæðum pess að skapast hefur ótti við bólusetningar meðal sumra foreldra, sérstaklega í Bandaríkjunum og á Bretlandi, enda var niðurstaða greinarinnar (ranglega) sú að meiri líkur væri á að bólusett börn próuðu með sér einhverfu.

36 Sjá Finnur Dellsén, „Realism and the Absence of Rivals“, Synthese 2017, bls. 24272446, hér bls. 2438, og „Should Scientific Realists Embrace Theoretical Conservatism“, Studies in History and Philosopby of Science 4/2019, bls. 30-38, hér bls. 36. 
við ættum aldrei að hugsa á sjálfstæðan eða gagnrýnan hátt. Pvert á móti er pað í vissum tilvikum mikilvægt að við myndum okkur sjálf skoðanir með gagnrýnum hætti einmitt vegna pess að ef við gerum pað ekki pá er síður hægt að taka mark á pví sem sérfræðingar á tilteknu sviði hafa að segja.

Til að sjá hvernig á pessu stendur skulum við byrja á að velta pví fyrir okkur hvaða áhrif pað hefði á skoðanamyndun hóps ef einstaklingarnir í hópnum treysta hver öðrum frekar en að mynda sér sjálfstæðar skoðanir. Til einföldunar getum við ímyndað okkur tvo hópa sem eru eins ólíkir að pessu leyti og mögulegt er: Fyrri hópurinn samanstendur einungis af „sjálfstæðum hugsuðum“, pað er að segja einstaklingum sem mynda sér skoðanir án pess að treysta nokkrum öðrum í hópnum; hinn hópurinn inniheldur einungis einn „sjálfstæðan hugsuð“ sem hinir meðlimir hópsins treysta í blindni. ${ }^{37}$ Við sjáum í hendi okkar að í slíku dæmi er fyrri hópurinn líklegri til að hafa rétt fyrir sér pegar hann kemst að sameiginlegri niðurstöðu, vegna pess að seinni hópurinn kemst óbjákvæmilega að sameiginlegri niðurstöðu en pað sama gildir ekki um fyrri hópinn. Til að fyrri hópurinn komist að sameiginlegri niðurstöðu purfa allir einstaklingarnir í hópnum að hafa myndað sér sömu skoðun óháð hinum einstaklingunum, sem er verulega ólíklegt nema að viðkomandi skoðanir séu í reynd vel rökstuddar.

Petta má skýra betur með einföldu dæmi. Ímyndum okkur að við legðum reikningsdæmi fyrir 100 einstaklinga og bæðum pá um að leysa dæmið sjálfa. Væntanlega pætti okkur pað pá góð vísbending um að svarið við dæminu sé 42 ef allir eða næstum allir einstaklingarnir kæmust að peirri niðurstöðu. Til samanburðar mætti ímynda sér að við skipuðum 99 af pessum 100 einstaklingum að afrita svarið frá peim eina einstaklingi sem væri eftir. Pá væri sú staðreynd að peir kæmust að sömu niðurstöðu alls ekki ástæða til að halda að svarið peirra sé rétt, enda getum við sagt okkur pað fyrirfram að einstaklingarnir myndu komast að sömu niðurstöðu (að pví gefnu að peir fylgdu fyrirmælum okkar). Petta bendir til pess að pað að fólk myndi sér sjálfstæðar skoðanir geri að verkum að við höfum ríkari ástæðu til að trúa pví sem fólk er sammála um.

Pessi niðurstaða gildir raunar ekki aðeins um einfölduð dæmi af pessu tagi par sem annar hópurinn inniheldur einungis „sjálfstæða hugsuði“ en hinn hópurinn inniheldur bara einn „sjálfstæðan hugsuð“. Almennt gildir að eftir pví sem skoðanamyndun einstaklinga í hópi er hádari, peim mun minni

37 Einhver í hópnum verður að mynda sér sjálfstæðar skoðanir svo að hinir einstaklingarnir í hópnum geti myndað sér einhverjar skoðanir yfirleitt, pví annars hefði hinir einstaklingarnir engan til að herma eftir í skoðanamyndun sinni. 
líkur eru á að sameiginleg niðurstaða einstaklinganna sé rétt, að pví gefnu að öðrum páttum sé haldið jöfnum. Hugtakið hœði (e. dependence) er hér skilgreint sem hlutfallið á milli líkanna á pví að tilteknar fullyrðingar séu allar sannar og margfeldi líkanna á pví að hver og ein fullyrðing sé sönn. Eftir pví sem skoðanamyndun einstaklinga í hópi er háðari pá höfum við meiri ástæðu til að ætla að einstaklingarnir muni komast að sameiginlegri niðurstöðu óháð pví hvort sú fullyrðing sé sönn eða vel rökstudd. Af pví leiðir svo að peim mun óháðari sem einstaklingarnir eru, peim mun líklegra er að sameiginleg niðurstaða peirra sé rétt. ${ }^{38}$

Ástæða pess að ég dreg pessa líkindafræðilegu niðurstöðu fram í dagsljósið er að petta sýnir hvers vegna pað skiptir máli að sérfreðingar myndi sér skoðanir með sjálfstæðum hætti. Nánar tiltekið sýnir petta hvers vegna mikilvægt er að fólk myndi sér skoðanir með sjálfstæðum hætti á álitamálum sem pað sjálft telst vera sérfræðingar um. Мeð pví að hugsa sjálfstætt um efni á sínu eigin sérsviði stuðlar maður að pví að hægt sé að treysta pví sem sérfræðingarnir á pessu sérsviði eru sammála um. Til dæmis skiptir máli að höfundur pessarar greinar hugsi sjálfstætt um efni hennar - traust á sérfræðingum - vegna pess að ef hann gerir pað ekki er síður hægt að treysta á pað sem sérfræðingar á sviði félagspekkingarfræði segjast vera sammála um. Ef ég og aðrir fræðimenn á sviðinu fylgdu einum tilteknum fræðimanni að málum gagnrýnislaust, pá hefou lesendur pessarar greinar minni ástæðu til að trúa pví sem félagspekkingarfræðingar hafa sammælst um.

Niðurstaðan af pessu er pví sú að sjálfstæð hugsun sérfræðinga hafi ákveðið samfélagslegt gildi. Sjálfstæð hugsun er gagnleg fyrir samfélagið í heild sinni að pví leyti að við purfum öll að reiða okkur á sérfræðipekkingu annarra. Pegar við stólum á slíka sérfræðibekkingu pá purfum við að höfða til pess sem almenn samstaða ríkir um meðal sérfræðinga, en slík samstaða er aðeins til marks um að pað sem um er að ræða eigi við rök að styðjast að pví marki sem sérfræðingarnir hafa myndað sér skoðanir með sjálfstæðum hætti. Í mjög stuttu máli er niðurstaðan pví sú að sérfreðingar purfa að bugsa sjálfstett til pess að við hin getum treyst peim. Við petta má bæta að við erum öll sérfræðingar í einhverju - til dæmis erum við öll sérfræðingar um hluti sem snúa að okkar eigin lífi - svo að pessi skylda til að hugsa sjálfstætt hvílir á okkur öllum að einhverju leyti. Peir sem gegna hlutverki sérfræðinga í opin-

38 Sjá ítarlegri og formlegri útgáfu af pessari rökfærslu í Finnur Dellsén, „The Epistemic Value of Expert Autonomy“, bls. 351-358. Annars konar rök fyrir samskonar niðurstöðu má finna hjá Cailin O’Connor og James Owen Weatherall, The Misinformation Age. How False Beliefs Spread, New Haven: Yale University Press, 2019. 
berri umræðu hafa hins vegar sérstaklega ríka skyldu til að hugsa sjálfstætt í stað pess að fylgja öðrum sérfræðingum að málum.

Vert er að athuga að pessi samfélagslega skylda til sjálfstæðrar hugsunar snýst ekki um að sérfræðingarnir verði sjálfir betur settir við pað að komast að eigin niðurstöðu. Yfirleitt er bæði einfaldara og pægilegra fyrir sérfræðinga að treysta öðrum sérfræðingum frekar en að komast að eigin niðurstöðu, enda tekur pað tíma og orku að afla sér upplýsinga og íhuga hvaða afstöðu sé rétt að taka. Ætla má að Frederick Mishkin og Tryggvi Pór Herbertsson hafi einmitt af pessum ástæðum valið að treysta áhættumati Fjármálaeftirlitsins í stað pess að leggjast í sjálfstæða rannsókn á stöðu íslensku bankanna, eins og peir voru gagnrýndir fyrir að gera í skýrslu rannsóknarnefndar Alpingis. Auk pess vitum við oft að aðrir sérfræðingar séu jafn líklegir, eða jafnvel líklegri, til að komast að réttri niðurstöðu um efni sem liggja pó innan okkar sérsviðs. Ég hef hins vegar fært rök fyrir pví að sérfræðingum beri samfélagsleg skylda til að treysta ekki öðrum sérfræðingum um mál á peirra eigin sérsviði, pví annars geta aðrir síður treyst pví sem slíkir sérfræðingar geta sammælst um. Gildi sjálfstæðrar hugsunar liggur pví ekki í pví að auka líkurnar á að við höfum sjálf rétt fyrir okkur, heldur í pví að tryggja að aðrir geti treyst okkur pegar við gegnum hlutverki sérfræðinga.

Petta má kannski orða pannig að að svo miklu leyti sem við eigum að bugsa sjálf pá eigum við að gera pað fyrir aðra - ekki fyrir okkur sjálf.

\section{Lokaorð}

Pegar pessi lokaorð eru skrifuð - í lok mars 2020 - er aðeins mánuður síðan kórónuveiran sem veldur COVID-19 greindist fyrst í einstaklingi hér á landi. Líf allra landsmanna (og flestra annarra jarðarbúa) hefur nú pegar tekið stakkaskiptum vegna faraldursins, meðal annars vegna samkomubanns, breytinga á skólahaldi og pess að púsundir einstaklinga eru í sóttkví. Pessar aðstæður minna okkur rækilega á mikilvægi sérfræðinga í samfélaginu, enda eru einmitt sérfræðingar á borð við sóttvarnalækni og landlækni sem almenningur og stjórnvöld purfa að reiða sig á í aðstæðum af pessu tagi. Pótt hægt sé að meta gögn og rök pessara sérfræðinga í einhverjum tilvikum pá er óhjákvæmilegt að peim sé einnig treyst um mikilvæg atriði, svo sem um hvernig best sé að komast hjá smiti og hvernig faraldurinn muni próast á næstu vikum og mánuðum. Ýmsir aðrir „sérfræðingar“ - raunverulegir jafnt sem sjálfskipaðir - hafa einnig komið fram á sjónarsviðið með kenningar, líkön og framtíðarspár af ýmsum gerðum. Hverjum peirra eigum við 
að treysta, og af hverju? Og hvernig eiga pessir sérfræðingar að haga sér pannig að við hin höfum sem mesta ástæðu til að treysta peim? Og hvað felst eiginlega í pví að vera sérfræðingur á sviði kórónuveirunnar?

Ég vona að pessi grein hjálpi okkur að svara spurningum af pessu tagi. Í upphafi greinarinnar skilgreindi ég traust til sérfræðinga pannig að í pví felist að hneigjast til að trúa pví sem sérfræðingar segja um sitt sérsvið $i$ krafti pess að peir segja pað frekar en til dæmis í krafti peirra raka sem sérfræðingarnir kynnu að færa fyrir máli sínu. Ég færði svo rök fyrir pví að traust á sérfræðingum sé mikilvægt og oft nauðsynlegt, meðal annars vegna pess að við getum ekki kynnt okkur alla hluti sjálf. Pá stakk ég upp á pví að við ættum að treysta sérfræðingum pegar ýmsir félagspekkingarfræðilegir bættir eins og samsetning, fyrri reynsla, fjölbreytni og hvatar hníga að pví. Аð lokum færði ég rök fyrir bví að fólk ætti að hugsa sjálfstætt á peim sviðum par sem pað er sjálft í hlutverki sérfræðings vegna pess að pað eykur trúverðugleika sameiginlegra niðurstaðna pess sérfræðingahóps sem pað er hluti af. ${ }^{39}$

\section{ÚT D RÁTT UR}

\section{Að treysta sérfræðingum: Hvað, hvenær og hvers vegna?}

Til pess að sérfræðingar geti pjónað hlutverki sínu parf fólk að treysta peim pegar sérfræðingarnir tjá sig um sitt sérsvið. Á hinn bóginn virðist líka eftirsóknarvert að hugsa sjálfstætt og gagnrýnið um niðurstöður sérfræðinga - að trúa ekki endilega pví sem manni er sagt. Ég ætla að velta pessari togstreitu fyrir mér og reyna að svara fjórum nátengdum spurningum: (1) Hvað felst eiginlega í pví að treysta sérfræðingum? (2) Hvers vegna purfum við oft að treysta sérfræðingum? (3) Hvaða sérfræðingum eigum við helst að treysta, og í hvaða kringumstæðum? (4) Og í hvaða kringumstæðum er mikilvægt að við hugsum gagnrýnið og komumst sjálf að rökstuddri niðurstöðu?

Lykilorð: sérfræðingar, traust, sjálfstæð hugsun, skoðanamyndun, félagsleg pekkingarfræð $\mathrm{i}$

${ }_{39}$ Ég vil bakka Eiríki Smára Sigurðarsyni, tveimur ritrýnum Ritsins og ekki síst ritstjórum pess fyrir mjög gagnlegar og uppbyggilegar athugasemdir við fyrri drög að pessari grein. Einnig vil ég pakka fyrir margar góðar athugasemdir og spurningar sem ég fékk pegar ég flutti fyrirlestra um petta efni á vegum forsætisráðuneytisins 28. nóvember 2019 og á Hátíðasal Háskóla Íslands 3. desember 2019. 


\section{A B S T R A C T}

\section{Trusting Experts: What, When, and Why?}

In order for experts to serve as authorities in our society, people need to trust them regarding when they make claims that fall within their domains of expertise. However, it also seems important for people to think independently and critically about the experts' conclusions - one should not believe everything one is told. In this paper, I examine this tension with the aim of answering four closely related questions: (1) What is it to trust experts? (2) Why do we often have to rely on experts? (3) Which experts should we trust more than others, and in what circumstances? (4) And in what circumstances is it important to think critically and try to reach our own conclusions?

Keywords: experts, trust, critical thinking, belief formation, social epistemology

\section{Finnur Dellsén}

Dósent í heimspeki

Sagnfræði og heimspekideild

Hugvísindasviði Háskóla Íslands

Sæmundargötu 2

102 Reykjavík, Ísland

fud@hi.is

Prófessor II í heimspeki

Deild heimspeki, lögfræði og albjóðafræða

Inland Norway University of Applied Sciences

Gudbrandsdalsvegen 350

2624 Lillehammer, Noregur

finnur.dellsen@inn.no 
